\section{THE LEISURE OF YOUNG PEOPLE IN CONTEMPORARY SOCIETY}

\author{
Ken Roberts \\ School of Sociology and Social Policy \\ University of Liverpool \\ Eleanor Rathbone Building \\ Bedford Street South \\ Liverpool L69 7ZA \\ England \\ k.roberts@liverpool.ac.uk
}

\section{EL OCIO DE LOS JÓVENES EN LA SOCIEDAD CONTEMPORÁNEA}

\begin{abstract}
RESUMEN: Este artículo examina cómo ha cambiado el ocio de los jóvenes en Europa occidental desde los años 50. Considera los efectos de la extensión de la etapa vital de la juventud, el ingreso en una era post-industrial y el notable aumento del gasto en ocio. El artículo explora las maneras en que las culturas juveniles se han convertido ahora en medios donde las relaciones y divisiones sociales son transformadas antes que reproducidas, y argumenta que esto es más plausible en relación al género, para algunas -aunque no todas- las divisiones étnicas, y totalmente implausible en relación a la clase social. Se aduce que las diferencias de clase en la socialización del ocio durante la infancia, que resultan en la adquisición de diferentes cantidades y tipos de capital cultural, junto a las relaciones sociales formadas entre pares sociales, permiten que las diferencias de clase se mantengan a lo largo de la etapa vital de la juventud, incluso aunque los jóvenes en la mayoría de trayectorias de clase compartan gran parte de su ocio.
\end{abstract}

PALABRAS CLAVE: Capital cultural; ocio; post-industrialismo; capital social; juventud.

\section{INTRODUCTION}

Childhood and youth are of special interest to leisure researchers because these are the life stages when individuals build-up stocks of leisure capital - skills, tastes and interests on which they base the rest of their leisure lives. Uses of leisure continue to change throughout the life course, but all subsequent changes are necessarily from foundations laid earlier-on. Leisure is of interest to sociologists of youth primarily for what is can reveal about social divisions: for example, whether class, gender and ethnic divisions are the basis for distinctive youth cultures and lifestyles that unify those inside while deepening their separation from others.

Today youth lasts longer than in the past. It is a longer period throughout which individuals' futures remain indeter-

\begin{abstract}
This paper examines how the leisure of young people in Western Europe has changed since the 1950s. It considers the effects of the extension of the youth life stage, the shift into a post-industrial era, and the steep increases in leisure spending that have occurred. The paper considers the ways in which youth cultures have now become milieu where social relationships and divisions are changed rather than reproduced, argues that this is most plausible in relation to gender, for some but not all ethnic divisions, and wholly implausible in relation to social class. It is argued that class differences in childhood leisure socialisation which result in the acquisition of different amounts and types of cultural capital, plus the social relationships formed among social equals, enable class differences to be maintained throughout the youth life stage even though young people on most social class trajectories share much leisure in common.
\end{abstract}

KEY WORDS: Cultural capital; leisure; post-industrialism; social capital; youth.

minate. Young people may entertain hopes, aspirations and expectations, but they cannot be certain about the kinds of adults that they will become. Some youth sociologists (see below) contend that present-day young people's leisure (or consumption) is eroding traditional social divisions which are being replaced by divisions and identities based on leisure (or consumer) styles, and suggest that these identities may be retained throughout post-modern adulthoods. The following passages urge discrimination. They argue that youth leisure as a melting pot for traditional divisions is plausible in relation to gender, may apply to ethnic divisions if an outcome of youth is inter-marriage, but are wholly implausible in relation to class.

Leisure is highly context dependent, so it is necessary to specify the times and places to which the following analysis refers. It is about young people in Western Europe since the 
1950s. Former communist countries are different in so far as communism itself, and the subsequent transition, have left legacies for young people in these countries. North America, along with Australasia, has different ethnic characteristics. Also, in the USA completion of high school at age 18/19 became normal in the 1930s, and by the end of the 1960s over a half of young people were progressing into college. In most of Europe these levels of enrolment in education have been achieved only since the 1960s. The rest of the world, including the new industrial societies of Asia and Latin America, are different in that, in most of these countries, large proportions of their populations are still not absorbed into, and may never become part of, the modern economic sectors. Also, these countries have modernised directly into a late- $20^{\text {th }}$ and early-2 $21^{\text {st }}$ century world of global capitalism, markets, media and consumer cultures.

The time period dealt with below is 1950s onwards. Since then and up to the present-day, probably the best known European studies of young people's leisure have been those conducted in the UK, at Birmingham University's Centre for Contemporary Cultural Studies (CCCS) in the 1960s and 70s (Hall and Jefferson, 1976; Mungham and Pearson, 1976). The central claim of these studies was that the new postwar working class youth cultures were to be understood as forms of class resistance, offering "magical" solutions to the problems of growing-up working class amid the post-war economic and social changes. Britain was the source of these studies probably because the country was among the fastest to recover from the war, and before the war it had one of the world's highest standards of living. Other West European countries soon caught up and had their own versions of the Teddy Boys, mods, rockers and skinheads. The accuracy of the CCCS accounts of post-war youth cultures continues to be debated. The authors claimed to be supportive of ethnography, but their own fieldwork, at best, was superficial. This is one reason why there are continuing controversies about the extent and ways in which youth cultures have changed since the 1960s (see Muggleton, 2000, 2005). However, there is no dispute that there have been major changes. The changes themselves, all with implications for young people's leisure, and the forces responsible, have been broadly the same throughout Western Europe:

- The lengthening of the youth life stage.

- The shift into a post-industrial age.

- Vast growth in leisure spending.

\section{Changes}

\section{The youth life stage}

In the 1950s and 60s youth was popularly known as a brief flowering period (Klein, 1965). Young people became full participants in youth cultures only after they left school and started earning wages (which was at age 14-16 for the majority in Europe at that time). Post-war "affluence" meant that they could afford to buy transistor radios, record players, singles, fashion clothing, and (by boys) personal motor transport, usually a scooter or motor bike. Girls usually earned less than boys: at that time sex discrimination was lawful and normal. Youth ended with marriage. At that time in northern Europe working class girls typically married in their late-teens or early-20s; the grooms were typically one or two years older. Very few young men actually became Teddy Boys: rather more probably adopted the later styles and became mods, rockers or skinheads, or more likely had these labels applied to them by others. These "types" were originally cultural constructs with which young people could align themselves, or find themselves typecast by others (see Cohen, 1972). For most young people, these types were just part of an exciting world within which they led their own more prosaic leisure lives (as portrayed, for example, in Willmott, 1966).

All these youth cultures were male-led. At that time teenage girls' independent leisure was often spent in bedrooms: they needed boyfriends before they could "go out" (Griffin, 1985). The youth cultures were all working class youth cultures. Being "on scene" was tantamount to being antischool and eager to leave at the first opportunity (Sugarman, 1967). Middle class young people who experienced an extended education were kept, or kept themselves, apart. Working class early school-leavers were earning the wages that gave them money to spend, and enhanced their status within their families.

Middle class and "square" were decoupled in the 1960s. University students led the way. Beatniks and hippies began appearing on campuses across the Western world. Sherry parties were "out": beer, sex and drugs were "in". Students became politicised and demonstrated in the original postwar new social movements. Their first cause célèbre was for civil rights in the USA. This was followed by opposi- 
tion to the Vietnam War which spread student protests into Europe. The aims gradually widened into rejection of the entire capitalist-industrial- military system. Academics tried to understand all this (see Feuer, 1969, Roszak, 1970). One point of agreement was that these student movements were quite different from the working class youth cultures of that era. The student movements attracted as much if not more academic and media attention as their working class counterparts, though at that time in Europe only small minorities of young people were attending universities. A new post-war middle class generation was then being born (Inglehart, 1977), but at the time this was not properly understood. One similarity between working and middle class youth experience was that in both cases it tended to end abruptly - on marriage for the working class, and on graduation for students after which they embarked on middle class careers.

Today youth is a different kind of life stage. University students have become the largest single youth career group in country-after-country. Chances of obtaining full-time, permanent adult employment have receded. It now takes until age 29 before the majority in the EU27 occupy such jobs (Social Agenda, 2009). Typical ages of marriage and first child births have risen in northern Europe to late20 s or early-30s for women, and slightly older for men. In southern Europe it remained normal for young people to remain at home with their parents until they married in their late-20s or 30s throughout the post-war decades (see Holdsworth, 2005). The expectation in the north at that time was that eventually the "backward" south would catch-up, but in practice it is the north that has changed and its young people's family and household formation practices have become southern, except that in the north young people still leave their parents' homes earlier to live singly, in shared housing or to cohabit - now a normal prelude or alternative to marriage (see Heath and Kenyon, 2001; Rugg et al., 2004). Youth family and housing careers have become far more complicated than when a couple would leave their parents' homes, marry, start life in their marital home, and both lose their virginity, all within a single day (Leonard, 1980).

Exclusion from adult jobs has not impoverished Europe's teenagers and 20 -somethings. The majority have sufficient income from parents (the so-called "bank of mum and dad"), part-time and temporary jobs, and student grants and loans, to sustain thriving town- and city-centre nighttime economies. They participate from their teenage years, through their 20s, and often into their 30s (Hollands, 1995). Youth ends later than in the past, but if anything it now starts at younger chronological ages than formerly. This is indicated if not caused by the energetic marketing of youth fashions and music to the pre-teens. Pocket money has made the "tweenies" a sought-after commercial market segment. An outcome is that there are now age grades within the youth life stage and in youth leisuretime cultures. Arnett (2005) has labeled 18-25 as the age of "emerging adulthood" in North America, where the term "youth" remains firmly attached to the high school years, whereas in Europe "youth" remains an acceptable and understood descriptor of the now extended life stage. Arnett portrays America's 20-somethings as deliberately pausing growing-up in order to extend the period of life when they are free from adult responsibilities. Others would describe the age group's situation as being unable to advance due to their inability to access the necessary jobs and housing. However, it appears that everywhere the 20-somethings are at ease with their extended transitional life stage situations (see Devadason, 2007).

As in all life stages, "youth" are a constantly flowing stream. They move on and pass through. Nowadays they stay longer, so membership of the life stage group is replenished more slowly, and there are successive steps within youth. "Mature" 18 year olds do not mix with 14 year old "kids", and the 20-somethings do not hang around with mere teenagers. An outcome is greater diversity and less rapid obsolescence in youth scenes, tastes and fashions. Another effect of the lengthening of this life stage is that most participants are legally adult - able to vote and to access the full range of adult goods and services. Some older members of the life stage group earn good adult salaries. They, rather than teenagers, are the prime targets of consumer industries, and they serve as role models for younger young people.

\section{Post-industrial society}

The extension of youth has been just one part of a wider constellation of changes leading into a post-industrial age. As the name implies, economic change has been at the heart of this wider historical shift. Employment in extractive and manufacturing industries has declined. Jobs 
have been lost to new technology or exported to lower wage-cost countries. There has been a corresponding and compensating growth in service sector employment. Many of these new jobs require qualities and skills traditionally considered feminine. This is just part of the explanation of increasing rates of labour market participation by women. The contraceptive pill, available since 1961, has also played a part, giving women greater control than ever before over their own fertility and sexuality. Women today are spending a greater proportion of their adult lives in employment than during the industrial age. This is the context in which they have demanded, and been given, the legal right to equal opportunities and equal pay for work of equal value.

Towards the end of the $20^{\text {th }}$ century the first cohorts of boys and girls grew up in households with working mothers. The girls have taken it for granted that they will embark on long-term employment careers. Nowadays young women take maternity leave (another legal entitlement) instead of terminating their employment. This is the context in which girls have begun out-performing boys at all levels in education, starting in elementary school, continuing through secondary education, then resulting in female majorities among students in higher education. On entering the labour market they are now as successful as young men in terms of their chances of obtaining jobs and their rates of pay, and this equality continues for as long as the women remain childless.

The shift of employment into service sectors has led to traditional working class jobs being partly replaced by new service sector proletarian occupations in retail, hospitality, call centres, security firms, and as nannies, cleaners and gardeners in the private homes of the better-off (Bernadi and Garrido, 2008). Students often take these jobs as part-time or temporary occupations, but for others there is no escape from this kind of work. Traditional working class masculinity, which was required to perform heavy industrial work, is becoming obsolete, though many young working class males continue to aspire to this kind of employment (McDowell, 2003), and may preserve traditional masculine identities in their leisure (Blackshaw, 2003). However, they are likely to encounter a shortage of traditionally feminine young women, and those that remain confront severe shortages of reliable male working class "breadwinners". Hence the pressure on young women to make themselves economically independent.
The most rapid employment growth has been in the management and professional grades. Many of these jobs are in financial and business services. Others are in public administration, health care and education. In manufacturing highly qualified scientists and technologists who design and control mechanised production have replaced thousands of manual workers. The manual working classes have become minorities in the advanced post-industrial societies. This means that most children are now reared in middle class homes. The parents have middle class aspirations for their children and want them to succeed in education. This is the context in which progressing through upper secondary and into tertiary (what used to be called higher) education has become normal. The USA has now been overtaken in participation rates by some European and new industrial countries such as Singapore and South Korea. The number of graduates entering the labour market has expanded in all world regions (Morley, 2007). This has made highly qualified labour plentiful, and often cheap as well (Brown et al., 2010). Students are now core participants in youth/ young singles scenes. An extended education is a condition for remaining "in"; a total reversal of the situation in the 1950s. Secondary school pupils hope to become part of the student lifestyle, which is quite likely to be retained after graduation, especially by those who become part of the so-called $€ 1,000$ generation (see Chiotaki-Poulou and Sakallariou, 2010; Cuzzocrea and Tavani, 2010).

There are still distinguishable working class youth cultures. In the UK "chavs" express defiance (as Teddy Boys once did) simply by hanging around in trainers, tracksuits and hoods, or alternatively by wearing Burberry and "bling" (cheap ostentatious jewelry) (McCulloch et al., 2006; Nayak, 2006). The difference vis-à-vis earlier times is that these are no longer mainstream youth scenes. Mainstream youth cultures, like mainstream consumer cultures, are now middle class. There is also a lower class, sometimes described as an underclass or excluded, where children are reared in households with no-one in regular employment, in neighbourhoods where such households are common. The young people tend to disengage from education early. The girls may become single teenage mothers. Otherwise they hang about with local boys on the streets, take "fiddly jobs", commit petty offences, and sometimes become problem drug users (different from the "sensible" recreational drug use that is now mainstream) (see Parker et al., 2002). These young people find themselves unwanted in 
mainstream employment and excluded by the door policies of mainstream leisure facilities (see MacDonald and Shildrick, 2007).

Young men and women interact on equal terms in mainstream youth scenes. The teenage girls' bedroom culture is now a thing of the past. Groups of young women go out independently and claim public space - once a male prerogative - in town and city centres, bars and sports centres. An indication of the new times is gender convergence in rates of smoking, drug and alcohol consumption (Sweeting and West, 2003). Young males and females are equally likely to have paid employment. They have similar sources and levels of income. Couples go out together and share expenses: one no longer "takes" the other.

The shift from industrial into post-industrial economies has driven broader social changes. The economic changes themselves have several sources which include economic growth itself, the latest generation of information and communication technologies (ICT) and globalisation (to which ICT has contributed). Globalisation refers to the increased inter-country flows of goods, services, capital, people and information, and the creation of trans-national institutions which regulate these flows.

Movement by people is a flow that concerns us here. All West European countries are now net immigration countries. More people are moving because they are more aware than in the past of opportunities in other parts of the world, and simply because they can. The main flow today is from poorer to richer countries. Refugees from wars and political persecution join economic migrants in aiming for the relatively rich West. Former imperial countries attract migrants from former (and still remaining) colonies. Other migrants travel from all parts of the world. Since 2004 when the European Union expanded eastwards, there has been a new upsurge of migration from east into west Europe, and from 2012 this flow will be unrestricted.

Migration flows become self-sustaining. Trans-national networks are created which assist the movement and settlement of further migrants. A result is that some European towns and cities that have become migrants' favoured destinations are extremely multi-cultural. The UK does not have a particular large proportion of migrants in its total population compared with mainland West European countries. Even so, in London around 40\% of current working age residents were born outside the UK (Centre for Economic Performance, 2010). In the East European villages, towns and cities where future migrants are born and reared, migration is now a normal everyday topic of conversation and part of the life planning of young people. Migrants are typically young adults - not teenagers but in their 20s or 30s - and they have become substantial parts of the populations in the places where they settle. They compete for jobs, housing and other services with the local populations. Beck and Beck-Gernsheim (2009) claim that they are thereby helping to spread insecurity into Western Europe, and are simultaneously creating new trans-national communities of young migrants. Some are pendulum migrants who return to their home countries. Some stay: this always depends to some extent on the kinds of employment and accommodation that they are able to obtain, and whether romantic attachments are formed. Some who stay may assimilate, but this is likely to take at least a generation and to involve inter-marriage. Unlike the "new world", the relatively old ethnic nations of Europe are difficult to enter. Hyphenated identities are not really possible. People from local families will insist that they are the real Germans, French, British, Spanish and so on.

Nevertheless, many young people in Western Europe now grow up in multi-cultural environments. Students in higher education study alongside students from other countries, some of whom are from other EU countries, supported by EU Erasmus programmes. They will probably work alongside migrants. This fraternisation may or may not extend into leisure interests and spaces, but irrespective of inter-ethnic friendships, globalisation has introduced multi-cultural variety into the leisure offer in all parts of the world: the types of restaurants and foods that are available in city centres, the range of beers, wines and spirits available in bars, the fashion scenes, the kinds of music and entertainers. Top sport is now played for global crowds of spectators via the media. Europe's major football clubs compete season-long in Euro-competitions. Manchester United's travelling fans have become as familiar with Madrid and Barcelona as with Newcastle and Sunderland. This de-localisation of everyday leisure is one aspect of globalisation in the post-industrial age.

ARBOR Vol. 188754 marzo-abril [2012] 327-337 ISSN: 0210-1963

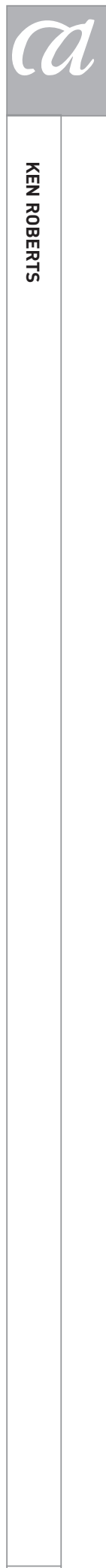




\section{Leisure}

Leisure studies was formed as an academic field in the 1950s and 60s. One of its major claims was that leisure had grown, was still growing, and that this growth would continue. Thus leisure was becoming a more important part of people's lives and of society-at-large. Hence the case for treating leisure seriously.

Predictions that leisure would continue to grow have proved correct, but the founders of leisure studies did not envisage exactly how leisure would grow over the next 40-50 years. They expected leisure spending to increase, but some of the gains from future economic growth were expected to be taken in the form of increased leisure time. This had been the pattern since the early days of industrialism and up to the 1960s. The normal working day, week and year had all been trimmed. In the event, the shift into a post-industrial age has seen an end to the former historical decline in normal hours of work. Another historical turn-around is that the management and professional grades now work longer, on average, than the lower level staff who they control. The higher socio-economic strata are no longer time privileged. All the benefits of economic growth have been taken in the form of higher incomes, and in Western countries pay has risen fastest in the occupations that were already better-paid, that is, managers and professional employees. Attempts in Germany and France to reduce hours of work so as to create more jobs and reduce unemployment have proved unsuccessful (see Roberts, 2006, 2007 for a review of the relevant evidence). The explanations of these trends are still debated, but one outcome is crystal clear: huge growth in leisure spending, mainly by the middle classes who have the higher incomes, and who are now as numerous as the working classes.

In the UK leisure spending has risen five-fold in real terms since the 1950s; that is, at more than three times the rate of the overall growth in spending. The more prosperous a country, the higher the proportion of its spending is devoted to leisure goods and services. The higher income groups within countries consistently spend the highest proportions of their incomes on leisure. All this was true before and throughout the 1950s and 60s. The subsequent explosion in leisure spending has been due to an apparent shift in time/money preferences towards all the benefits of growth being channeled into higher incomes, and the con- centration of these rises among the better-off. These have been new tendencies, somehow associated, although the ways remain unclear, with the shift into a post-industrial age. The leisure industries that have benefitted most from the increases in leisure spending are out-of-home dining and drinking, communications, and tourism. All age groups are now spending much more than in the past on these leisure goods and services. Young people have simply been part of general trends, but because young people have yet to acquire adult responsibilities, they can devote unusually large proportions of their incomes to leisure, and they have become a major market segment for the relevant leisure industries.

"Going out" has always been a pivotal youth leisure activity. The change over time has been in the amounts of money spent when young people go out. Young teenagers who merely "hang around" nowadays expect to have the money to purchase confectionery and soft drinks. Older teenagers might formerly have met in a coffee bar, gone to the cinema or a dance palais. Girls often entertained samesex friends in bedrooms where they played records, applied cosmetics and tried on clothes. A real night out is now a far more expensive affair (see Hollands, 1995). It involves taxi fares, food at some point, drinks in a bar throughout an evening, which will be a prelude to "clubbing" and the possible purchase of soft drugs. It is necessary to be fashionably attired for these occasions. "Binge drinking" is now normal youth leisure throughout Europe. Beer has become young people's favourite alcoholic beverage across the continent, though ready-mixed drinks (with a spirit base) are also popular. At least mild intoxication is considered a condition for real fun (Jarvinen and Grundelach, 2007). Night-time economies that keep Europe's city centres lively well into the wee small hours every weekend are sustained by young people's spending. As Hollands (1995) points out, this leisure behaviour continues throughout a prolonged youth life stage. Youth is no longer a brief transitional phase in which socio-psychological developmental tasks (like finding a mate) are accomplished after which the individuals move on. Youthful behaviour continues throughout the 20s and often well beyond.

Spending on communications has risen alongside ICT enlarging the ways in which it is possible to send and receive communications. It is necessary to have been born during or since the 1990s to have grown up amid the present 
range of technologies. Spending is on hardware, software, subscriptions and user charges.

- Electronic games were once played only on dedicated consoles, on a household TV screen, or in an arcade. These are all still common, but games can also be played on a hand-held device including mobile phones and over the internet. The games become forever more sophisticated technically, and more challenging. They are now part of a normal childhood and play is likely to continue throughout life.

- Multi-channel television makes it possible to watch any kind of programme at any time during any day or night.

- The mobile phone is now a multi-functional device enabling users to communicate by voice or text, to transmit and receive images, to listen to music, and to access the internet. Children now grow-up in a world where a mobile is absolutely essential in order to keep "in touch".

- The internet can be used for person-to-person communication (email), to obtain information for work, study or a leisure interest, to make purchases, to sell unwanted items, to conduct bank transactions, to download images, text and sound, to join interactive online communities, and to enjoy a second life in virtual reality. The internet has undermined certain leisure industries (recorded music for example) but it has created even more new ways of doing business. Among others, the internet has facilitated a huge expansion of the gambling industry.

Tourism is now one of the world's largest industries. Europeans now grow up regarding travel as a necessity. The motor car has become an essential acquisition while en route to adulthood. Present-day rites of passage include attending a pop concert, clubbing, a major pop festival, and holidaying abroad without adult supervision. There are travel companies, hotels and entire resorts which cater for the youth and young singles markets. The basic ingredients are cheap travel and accommodation, sunbathing, beach games, and opportunities to drink and dance throughout every night. West Europeans may also travel to study. They may make long-haul extended trips during gap years prior to, during or after university. These are excursions on which they may try to combine earning and pleasure. This has become a modern and mass equivalent of the "grand tour", originally undertaken by youth from aristocratic European families.

Young people's leisure has become intensely commercial, meaning that full participation requires substantial financial outlays. The main providers are all commercial businesses. Many young people are involved in voluntary associations which organise sport, artistic production and consumption, or undertake voluntary work. Some young people join political and religious organisations. However, all these forms of youth leisure are marginal (relatively small whether size is measured in the proportions who take part, or time or money spent) compared with what commerce offers. Traditional youth movements and clubs play virtually no part in present-day youth's leisure. These movements had their heyday before 1939. Most have survived, and some have flourished by targeting children, the under-14s, after which the age group is seeking something more grown-up.

Some young people are excluded or remain on the margins of today's commercial mainstream. This may be by choice or parental pressure, or more likely due to straight-forward lack of the necessary money to spend. It is necessary to spend in order to be a full participant in today's normal forms of youth leisure. This is a big change since the 1950s and 60s. Youth is now an extended life stage, in which most young people are on or are trying to join middle class life trajectories. Their leisure is intensely commercial and access is rationed by the ability and willingness to pay.

\section{Discussion}

\section{Social divisions}

We noted in the introduction that sociology's principal interest in young people's leisure is its potential contribution to knowledge about social divisions, and some students of youth cultures claim that these milieu are currently weakening divisions that were formed during the industrial era and creating alternatives. They have focused rather narrowly on night-life where music is played and fashions are displayed. They note the plethora of styles

ARBOR Vol. 188754 marzo-abril [2012] 327-337 ISSN: 0210-1963

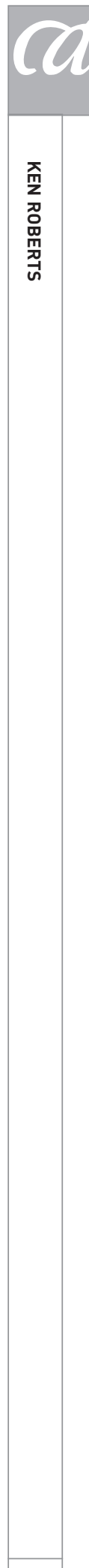

333 
with which present-day young people may align, either long-term of just temporarily. Individuals' alignments can be judged by how they dress, the pubs and clubs that they visit, and the music that they prefer. This evidence is used to suggest that we have entered a post-subcultural age (Bennett, 1999; Redhead, 1997; Thornton, 1995). This is because differences among present-day young people according to their styles and tastes do not map neatly onto social class or any other divisions. This is said to constitute a change since the 1960s, assuming that the CCCS claims about the youth cultures of that era were valid, which can be disputed. However, there is no dispute that young people are now presented with a much wider variety of styles. The CCCS researchers confronted a limited number of clearly defined youth sub-cultures. This apart, the post-subcultural claim rests on the observation that rather than pre-existing groups adopting particular styles, today's styles create new "tribes", to use Maffesoli's (1994) term. The post-subcultural claim is consistent with the majority of young people, then and now, being unwilling to identify with any particular style and insisting that they are simply "normal" or "ordinary" rather than "spectacular". Rather, they can express individuality by picking and mixing from the "market place". Just as music can now be blended into hybrid sounds, so individuals can create their own forms of hybridity. New styles, like the old styles, are basically cultural constructs which can be worked on by pre-existing groups or by individuals (usually within limits that are understood and approved by their particular peers). Technology, the expansion of the markets, and an intensification of competition are all credited with a role in these changes, along with changes in the youth life stage itself.

Today's young people typically relinquish childhood identities based on family origins many years prior to having adult destinations with which they can confidently identify. Miles (2000) claims that throughout the intervening years youth cultures can be a source of temporarily important identities. It is also possible that, in this extended youth life stage, divisions by class are permanently weakened, and gender relations are defined differently than in former times. Youth cultures could also act as a melting pot for ethnic divisions.

These claims are most plausible in relation to gender. Young males and females' levels of attainment in education and the labour market have converged. In youth cultures the sexes relate on equal terms. It is plausible, though not inevitable, that this symmetry will continue through family and household formation with males and females sharing the tasks of earning, housework and child care.

In respect of ethnic divisions, youth cultures will act as a melting pot if the different groups inter-mingle and eventually inter-marry. This seems most likely if the ethnicities are all European or at least Western. If there are physical and/or deep cultural differences in language, religion and preferred uses of leisure, especially if minorities do not embrace alcohol and night-life in the manner of European youth, their respective leisure practices are likely to consolidate the ethnic divisions in question.

As regards social class divisions, the melting pot hypothesis lacks plausibility. Childhoods are classed: children benefit from different types and amounts of financial, social and cultural capital depending on the class positions of their parents. Adulthoods are classed because different occupations are situated differently in the systems of economic production and distribution. It would be amazing if class differences disappeared completely during the intervening years. This cannot be the case, otherwise how might we explain persistent endogamy - the tendency for social equals to marry one another? (Blossfeld and Timm, 2003). Young people on all class trajectories may go on similar holidays, use the same communication technologies, consume alcohol, listen to the same range of sounds, visit bars and clubs, and wear similar clothing. However, they can do all this while remaining among close friends with similar social origins and educational backgrounds, who are heading towards similar class destinations (Hollands, 2002; MacRae, 2004). Also, as we shall see below, individuals from different social class backgrounds have acquired different types and amounts of cultural capital prior to entering youth scenes, and these differences do not lessen as they progress towards adulthood (Nagel, 2010).

\section{Leisure capital formation}

Leisure studies' interest in young people's leisure is primarily because this life stage, along with childhood, is when individuals acquire most of their basic leisure interests, tastes and skills. Thereafter leisure behaviour displays impressive continuities. Activities and interests may be dropped 
during adulthood and later life, but it is exceptional for entirely new interests to be taken-up and retained (see Maguire et al., 1987; Scott and Willits, 1989).

So what are children and young people learning? Clearly, they learn to be consumers. This is not difficult. Commerce always makes consumption easy. Children and young people also learn to play sports, from which drop-out begins in the mid-teenage years. Whether or not individuals continue to play appears to depend on a combination of sporting ability, the depth and breadth of their socialisation into sport, and how easy it is to remain involved (easiest while they remain in education). The main differences in children's and young people's leisure appear to lie in the depth and breadth of the cultural interests that they acquire, and whether they become active members of voluntary associations. Middle class families pass on relatively wide ranges of tastes and interests in the arts. We should note that this is not "instead of". The presentday middle classes are cultural and leisure omnivores, a feature first noted in the USA by Peterson in 1992. Since then omnivorous middle classes have been identified in numerous other places including Britain (Bennett et al., 2009; Roux et al., 2008). It is not via their highbrow tastes so much as the breadth of the interests that they can discuss and activate that the present-day middle classes make themselves distinctive, and make others feel that they are outsiders (Bourdieu, 1984; Peterson and Kern, 1996). Social class related differences in levels and breadth of cultural interests are formed before age 14, after which the differences neither widen nor narrow (Nagel, 2010).

There is a long history of using leisure programmes to try to redirect the lives of so-called "at risk" youth. After over a century of such efforts, Collins and Kay (2003) note that the evidence of effectiveness remains inconclusive. This means that none of the scores of evaluation studies have been able to demonstrate positive impacts beyond reasonable doubt. Actually we do have evidence from longitudinal birth cohort studies in the UK that leisure activities during youth do have long-term consequences that cannot be attributed to any other influences. Among the UK cohort born in 1970, membership of sports clubs, community and church groups at age 16 reduced risks of exclusion (unemployment, poverty, and trouble with the police and courts) up to age 30 (Feinstein et al., 2005). Teenage involvement in the arts also has long-term benefits (Robson, 2003). However, within the 1970 birth cohort, membership of youth clubs at age 16 marginally increased the participants' risks of exclusion by age 30 . The arts appear to be outstanding in their efficacy. The most likely explanation of the positive and negative outcomes is that they arise via the social composition of the participants in the relevant leisure milieu. Individuals' life trajectories are drawn towards the norms of the leisure groups in which they become involved.

It must be stressed that all the above leisure effects are minor compared with the predictive power of educational attainments and social class origins. Moreover, the processes whereby leisure makes a difference mean that leisure will never improve the life chances of all disadvantaged young people. If they all joined church and community groups, they would change the social composition of the participants and thereby eliminate any positive effects. Another perspective on this is that the middle classes have a vested interest in keeping themselves apart, which they achieve mainly through socialising their children into appreciation of the arts, encouraging them to join and become active in clubs, and to a lesser extent through sport.

\section{REFERENCES}

Arnett, J. J. (2005): Emerging Adulthood: The Winding Road from Late Teens

Recibido: 18 de mayo de 2011 Aceptado: 21 de julio de 2011 Through the Twenties, Oxford University Press, Oxford.
Beck, U. and Beck-Gernsheim, E. (2009): "Global generations and the trap of methodological nationalism for a cosmopolitan turn in the sociology of youth and generation", European Sociological Review, 25, 25-36. 
Bennett, A. (1999): "Subcultures or neotribes? Rethinking the relationship between youth style and musical taste", Sociology, 33, 599-617.

Bennett, T.; Savage, M.; Silva, E.; Warde, A.; Gayo-Cal, M. and Wright, D. (2009): Culture, Class, Distinction, Routledge, London.

Bernadi, F. and Garrido, L. (2008): "Is there a new service proletariat? Post-industrial employment growth and social inequality in Spain", European Sociological Review, 24, 299-313.

Blackshaw, T. (2003): Leisure Life: Myth, Masculinity and Modernity, Routledge, London.

Blossfeld, H.-P. and Timm, A. (eds.) (2003): Who Marries Whom? Educational Systems as Marriage Markets in Modern Societies, Kluwer, Dordrecht.

Bourdieu, P. (1984): Distinction: A Social Critique of the Judgement of Taste, Routledge, London.

Brown, P.; Ashton, D. and Lauder, H. (2010): Skills are not Enough: The Globalisation of Knowledge and the Future of the UK Economy, Praxis, 4, March 2010, UK Commission for Employment and Skills, London.

Centre for Economic Performance (2010): Immigration and the UK Labour Market: The Evidence from Economic Research, Centre for Economic Performance, London School of Economics, London.

Chiotaki-Poulou, I. and Sakallariou, A. (2010): "Youth in Greek society and the '700 Euro generation': the rise of a new generation?", paper presented at midterm conference of the European Sociological Association Youth and Generation Network, Youth, Economy and Society, Disley.

Cohen, S. (1972): Folk Devils and Moral Panics, MacGibbon and Kee, London.

Collins, M. F. and Kay, T. (2003): Sport and Social Exclusion, Routledge, London.
Cuzzocrea, V. and Tavani, C. (2010): "Superimposing discourses on qualified youth: the case of Law 7/2007 of the Autonomous Region of Sardinia", paper presented at midterm conference of the European Sociological Association Youth and Generation Network, Youth, Economy and Society, Disley.

Devadason, R. (2007): "Constructing coherence? Young adults' pursuit of meaning through multiple transitions between work, education and unemployment", Journal of Youth Studies, 10, 203-211.

Feinstein, L.; Bynner, J. and Duckworth, K. (2005): Leisure Contexts in Adolescence and their Effects on Adult Outcomes, Institute of Education, London.

Feuer, L. S. (1969): The Conflict of Generations, Heinemann, London.

Griffin, C. (1985): Typical Girls?, Routledge, London.

Hall, S. and Jefferson, T. (eds.) (1976): Resistance Through Rituals, Hutchinson, London.

Heath, S. and Kenyon, L. (2001): "Single young professionals and shared household living", Journal of Youth Studies, 4, 83-100.

Holdsworth, C. (2005): "'When will the children leave home!' Family culture and delayed transitions in Spain", European Societies, 7, 547-566.

Hollands, R. (1995): Friday Night, Saturday Night, Department of Social Policy, University of Newcastle, Newcastleupon-Tyne.

Hollands, R. (2002): "Divisions in the dark: youth cultures, transitions and segmented consumption spaces in the night-time economy", Journal of Youth Studies, 5, 153-171.

Inglehart, R. (1977): The Silent Revolution, Princeton University Press, New Jersey.

Jarvinen, M. and Grundelach, P. (2007): "Teenage drinking: symbolic capital and distinction", Journal of Youth Studies, 10, 55-71.

Klein, J. (1965): Samples from English Cultures, 2 Vols, Routledge, London.

Leonard, D. (1980): Sex and Generation, Tavistock, London.

MacDonald, R. and Shildrick, T. (2007): "Street corner society: leisure careers, youth (sub)culture and social exclusion", Leisure Studies, 26, 339-355.

MacRae, R. (2004): "Notions of 'us' and 'them': markers of stratification in clubbing lifestyles", Journal of Youth Studies, 7, 55-71.

McCulloch, K.; Stewart, A. and Lovegreen, N. (2006): "'We just hang out together': youth cultures and social class", Journal of Youth Studies, 9, 539-556.

McDowell, L. (2003): Redundant Masculinities? Employment Change and White Working Class Youth, Blackwell, Oxford.

McGuire, F. A.; Dottavio, F. D. and O'Leary, J. T. (1987): "The relationship of early life experiences to later life leisure involvement", Leisure Sciences, 9, 251-257.

Maffesoli, M. (1994): The Time of the Tribes, Sage, London.

Miles, S. (2000): Youth Lifestyles in a Changing World, Open University Press, Buckingham.

Morley, L. (2007): "The X factor: employability, elitism and equity in graduate recruitment", 21 $1^{\text {st }}$ C Society, 2, 191207.

Muggleton, D. (2000): Inside Subculture: The Postmodern Meaning of Style, Berg, 0xford.

Muggleton, D. (2005): "From classlessness to subculture: a genealogy of postwar British youth cultural analysis", Young, 13, 205-219.

Mungham, G. and Pearson, G. (eds.) (1976): Working Class Youth Culture, Routledge, London. 
Nagel, I. (2010): "Cultural participation between the ages of 14 and 24: intergenerational transmission or cultural mobility?", European Sociological Review, 26, 541-556.

Nayak, A. (2006): "Displaced masculinities: chavs, youth and class in the post-industrial city", Sociology, 40, 813-831.

Parker, H.; Williams, L. and Aldridge, J. (2002): "The normalization of 'sensible' recreational drug use: further evidence from the north-west England longitudinal study", Sociology, 36, 941-964.

Peterson, R. A. (1992): "Understanding audience segmentation: from elite and mass to omnivore and univore", Poetics, 21, 243-258.

Peterson, R. A. and Kern, R. M. (1996): "Changing highbrow taste: from snob to omnivore", American Sociological Review, 61, 900-907.

Redhead, S. (1997): Subculture to Clubcultures, Blackwell, Oxford.
Roberts, K. (2006): Leisure in Contemporary Society, CABI, Wallingford.

Roberts, K. (2007): "Work-life balance - the sources of the contemporary problem and the probable outcomes: a review and interpretation of the evidence", Employee Relations, 29, 4, 334-351.

Robson, K. (2003): Teenage Time Use as Investment in Cultural Capital, Working Paper 2003-12, Institute of Social and Economic Research, University of Essex, Colchester.

Roszak, T. (1970): The Making of a Counter Culture, Faber, London.

Roux, B. Le; Rouanet, H.; Savage, M. and Warde, A. (2008): "Class and cultural division in the UK", Sociology, 42, 1049-1071.

Rugg, J.; Ford, J. and Burrows, R. (2004): "Housing advantage? The role of student renting in the constitution of housing biographies in the United Kingdom", Journal of Youth Studies, 7, 19-34.
Scott, D. and Willits, F. K. (1989): "Adolescent and adult leisure patterns: a 37 year follow-up study", Leisure Sciences, 11, 323-335.

Social Agenda (2009), "Youth unemployment: a challenge for Europe", Issue 20, March, 11-14.

Sugarman, B. (1967): "Involvement in youth culture, academic achievement and conformity in school", British Journal of Sociology, 18, 151-164.

Sweeting, H. and West, P. (2003): "Young people's leisure and risk-taking behaviours: changes in gender patterning in the West of Scotland during the 1990s", Journal of Youth Studies, 6, 391-412.

Thornton, S. (1995), Club Cultures: Music, Media and Subcultural Capital, Polity Press, Cambridge.

Willmott, P. (1966), Adolescent Boys of East London, Routledge, London. 